\title{
EFEKTIVITAS MANIPULASI "TOPURAK" UNTUK PENYEMBUHAN CEDERA SENDI LUTUT PASIEN LAB /KLINIK OLAHRAGA TERAPI DAN REHABILITASI FIK UNY
}

\author{
Oleh: \\ Muhammad Fathur Rohim dan Wara Kushartanti \\ Jurusan Pendidikan Kesehatan dan Rekreasi FIK UNY
}

\begin{abstract}
Abstrak
Cedera lutut yang ditandai dengan rasa nyeri merupakan cedera yang cukup sering. WHO 2008 menyatakan bahwa penderita nyeri sendi sebanyak 151 juta jiwa di dunia, hal ini merupakan sebuah kondisi yang sangat umum dialami oleh banyak orang, terutama bagi mereka yang banyak melakukan aktivitas fisik yang bertumpu pada lutut dan kaki. Penelitian ini bertujuan untuk mengetahui tingkat keefektifan manipulasi "Topurak" (totok, pukul, gerak) untuk penyembuhan cedera sendi lutut.

Metode pre-experimental design dengan rancangan One Group Pretest-Posttest Design digunakan dengan populasi pasien cedera sendi lutut di Lab/ Klinik Olahraga Terapi dan Rehabilitasi - FIK UNY, pada bulan Januari - April 2017 secara insidental. Dari 75 pasien yang ditangani selama penelitian diambil sebanyak 20 orang yang bersedia sebagai sampel. Setelah dilakukan pretest untuk menilai tanda radang dan fungsional lutut, diterapi dengan manipulasi Topurak sebanyak tiga kali dengan selangseling hari, dan masing-masing terapi berdurasi 5 menit. Setelah perlakuan terapi ke-tiga dilakukan post test. Semua data dideskripsikan, dan dilanjutkan dengan uji beda antara pretest dan post test untuk mengetahui seberapa efektivitas manipulasi Topurak. Hasil uji normalitas menunjukkan adanya distribusi normal pada data lingkar lutut atas, lingkar lutut tengah, skala nyeri, skala duduk berdiri, dan skala naik tangga, serta distribusi tidak normal pada lingkar lutut bawah, fleksi, ekstensi, dan skala kemampuan jalan. Uji beda dua kelompok berpasangan menggunakan sign test (non-parametrik).

Hasil uji beda menunjukkan bahwa manipulasi Topurak efektif $(\mathrm{p}<0,05)$ dalam menyembuhkan cedera sendi lutut yang ditunjukkan dengan menurunnya tanda radang, meningkatnya skala fungsi jalan, naik tangga dan duduk berdiri kecuali pembengkakan di lutut.
\end{abstract}

Kata kunci: topurak, cedera sendi lutut

Aktivitas yang dilakukan setiap hari ini akan menimbulkan keluhan otot, sendi, dan tulang (muskuloskeletal) pada tubuh. Keluhan ini biasanya tidak dihiraukan masyarakat karena belum memberikan efek yang berlebih. Gangguan muskuloskeletal yang sering dikeluhkan oleh pekerja maupun olahragawan adalah gangguan sendi lutut. Gangguan pada sendi lutut lebih sering dikeluhkan karena tugasnya menopang berat badan tubuh. Rasa sakit yang muncul pada lutut merupakan sebuah kondisi yang sangat umum dialami oleh banyak orang, terutama bagi mereka yang banyak melakukan aktivitas fisik yang bertumpu pada lutut dan 
kaki. Kebanyakan dari penyebab rasa sakit pada lutut adalah: terkilir, robeknya meniscus atau tulang rawan, radang pada tendo, dan kondisi lutut overuse (radang yang terjadi perlahanlahan karena gerakan yang berulang-ulang atau posisi statis yang dipertahankan lama). Semua itu dapat terjadi baik pada saat bekerja maupun berolahraga.

Banyak pengobatan yang dilakukan dalam upaya penyembuhan nyeri otot baik berupa terapi farmakologi maupun non-farmakologi. Terapi farmakologis merupakan pengobatan dengan obat, yang dalam hal nyeri sendi banyak digunakan analgesik golongan Non Steroid Anti Inflammatory Drugs (NSAID) yang berpotensi mempunyai efek yang kurang baik. Terapi non-farmakologis dapat menggunakan akupunktur, shiatsu, terapi panas, terapi dingin, chiropractic, massage dan lainnya. Model manipulasi Topurak (Totok, Pukul, Gerak) telah dikembangkan oleh Rachmah Laksmi A \& Wara Kushartanti (2016) untuk anggota badan bagian atas, dan hasil paling efektif terjadi pada reposisi bahu dan leher, dengan nilai efektivitas berturut-turut $96,7 \%$ dan $82,3 \%$.

Menurut Rachmah Laksmi A \& Wara Kushartanti (2016: 74) model reposisi Topurak ditujukkan untuk reposisi sendi yang terdiri atas pelemasan otot, tendo, dan jaringan ikat sekitar sendi dengan totok dan pukul, yang kemudian diikuti dengan penggeseran (reposisi) untuk mengembalikan sendi pada posisi semula dengan gerakan. Keunggulan Topurak adalah melibatkan pasien secara aktif, sehingga akan lebih aman dan nyaman, baik bagi pasien maupun terapisnya. Pasien diminta untuk menggerakkan sendi sesuai dengan arah range of motion (ROM) dan kecepatan sesuai dengan kekakuan dan nyerinya. Saat ini sedang dikembangkan manipulasi Topurak untuk panggul dan lutut. Penelitian merupakan bagian dari penelitian tersebut, khususnya untuk menguji efektivitas manipulasi Topurak untuk penyembuhan cedera sendi lutut.

\section{KAJIAN PUSTAKA}

\section{Patofisiologi Cedera Lutut}

Menurut Anderson (2009 : 651) cara berjalan laki-laki dan perempuan memiliki perbedaan, perempuan memiliki pinggul yang lebih besar, pinggul lebih adduksi, rotasi internal pinggul dan lutut abduksi dibandingkan laki laki. Penuaan merupakan proses menurunnya fungsi tubuh, sehingga meningkatkan kelemahan di sekitar sendi, penurunan kelenturan sendi, kalsifikasi tulang rawan dan menurunkan fungsi kondrosit. Hal ini menimbulkan terjadinya rawan cedera dan semuanya mendukung terjadinya osteoartritis (Eka Pratiwi Maharani, 2007 : 26).

Obesitas merupakan faktor risiko utama nyeri lutut. Hal ini dikarenakan, sendi pada lutut dan panggul adalah sendi weight bearing, sendi yang menahan beban tubuh. Selama berjalan, 
setengah berat badan bertumpu pada sendi lutut. Peningkatan berat badan akan melipatgandakan beban sendi lutut saat berjalan (Eka Pratiwi Maharani, 2007 : 30). Obesitas menyebabkan beban sendi abnormal dan menyebabkan perubahan dalam komposisi, struktur dan sifat tulang rawan artikular. Obesitas secara spesifik akan mengurangi massa otot dan kekuatan, stres mekanik dan peradangan sistemik dari waktu ke waktu, karena banyak jaringan adiposa sendi lutut tertekan untuk menahan beban dan menimbulkan inflamasi dalam jaringan sendi. (Heather K. Vincent, 2012 : 1). Lutut dapat menderita cedera traumatik atau overuse. Kelemahan dalam rangkaian kinetik, seperti stabilitas pergelangan kaki yang buruk menyebabkan rentan terhadap cedera lutut. Anderson (2009) membagi beberapa cedera, yaitu:

\section{A. Patela Tendinitis (Knee Jumper)}

Tendon patela sering meradang dan sakit karena aktivitas lutut berulang yang eksentrik, misalnya terjadi saat berjalan maupun olahraga seperti bola voli dan basket. Subluksasi patella, sindrom stres patellofemoral, dan kondisi lain juga dapat membebani tendon patella yang akan memperparah kondisi patela tendinitis. Faktor ekstrinsik yang dapat menyebabkan kondisi tersebut antara lain frekuensi latihan, lama bermain, permukaan tempat bermain, jenis latihan, peregangan dan praktek pemanasan, serta jenis sepatu yang dikenakan. Beberapa faktor intrinsik yang mungkin memiliki peran dalam memberikan kontribusi untuk kondisi ini termasuk malalignment ekstremitas bawah, perbedaan panjang kaki, ketidakseimbangan otot, variabel antropometri, panjang otot, dan kekuatan otot.

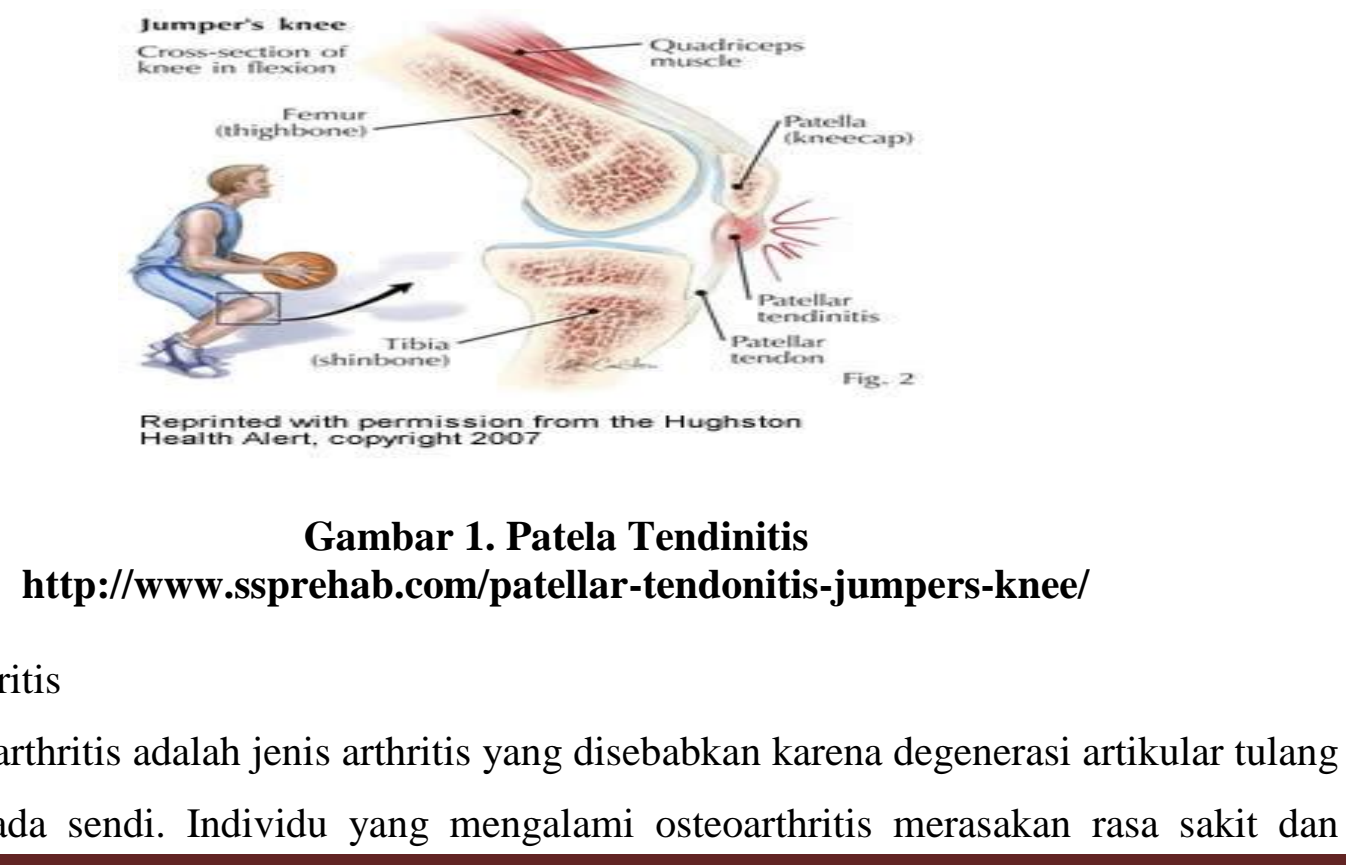


gerakan terbatas pada sendi yang terlibat. Osteoarthritis memiliki etiologi multifaktorial, yang terjadi karena interaksi antara faktor-faktor sistemik dan lokal. Banyak faktor yang menyebabkan, seperti tekanan berkelanjutan selama melakukan beberapa jenis aktivitas fisik, trauma sendi, overuse, dan proses penuaan (Anderson, 2009: 142). Osteoarthritis dapat mengenai semua usia, dan dipicu cedera pada sendi, obesitas, dan kerentanan genetik. Hal ini terlihat pada atlet remaja yang mengalami osteoarthritis dini (Behzad Heidari, 2011: 207). Menurut Eleftherios A. Makris (2011 : 7425), lesi meniscal mempunyai insidensi tinggi di antara beberapa kelompok usia pada populasi umum dengan faktor sekunder perubahan degeneratif pada tulang rawan artikular yang menyebabkan osteoarthritis.

C. Chondromalacia patelae (CMP)

Chondromalacia patelae (CMP) adalah perubahan degeneratif bertahap yang terjadi pada tulang rawan di bawah tempurung lutut dan pada permukaan tulang femur. Degenerasi ini disebabkan oleh trauma akut, berulang, mikro-trauma, dan posisi patella yang tidak tepat dalam alur femoralis atau jalur artikulasi. Patella dimanipulasi oleh empat otot paha depan yang berbeda, jika kekuatan otot tidak seimbang di setiap arah, maka patella dapat ditarik ke tepi alur bukannya berpusat, sehingga menyebabkan iritasi, dan dikenal sebagai CMP. Setiap jenis gaya tekan akan memperburuk kondisi ini. Atlet dengan CMP akan mengeluhkan rasa nyeri di sekitar patella yang menjadi lebih buruk selama squats, turun tangga, atau duduk untuk jangka waktu yang lama. Saat jongkok juga dapat menyebabkan rasa sakit. Seorang atlet dengan cedera ini mungkin memiliki pembengkakan berulang di wilayah patela, dan kekakuan di sekitar lutut setelah duduk untuk jangka waktu lama. Kekakuan ini kadang-kadang disebut "theater sign".

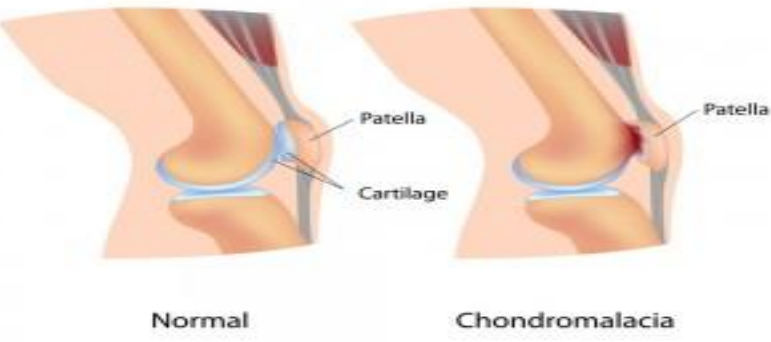

Gambar 2. Chondromalacia Patelae

http://www.iog.com.sg/chondromalacia-patellae/

D. Bursitis

Anderson (2009: 590) mengatakan bahwa bursitis adalah peradangan pada bursa sinovial yang dapat disebabkan oleh stres atau ketegangan yang berlebihan pada bursa. 
Gejala umum dari bursitis adalah pembengkakan dan nyeri di daerah prepatellar (prepatellar bursitis), terutama di kawasan tendon distal patela (infrapatellar bursitis dalam), di tibia medial proksimal (pes bursitis anserine), atau di atas medial sendi (tibialis ligamen kolateral bursitis)

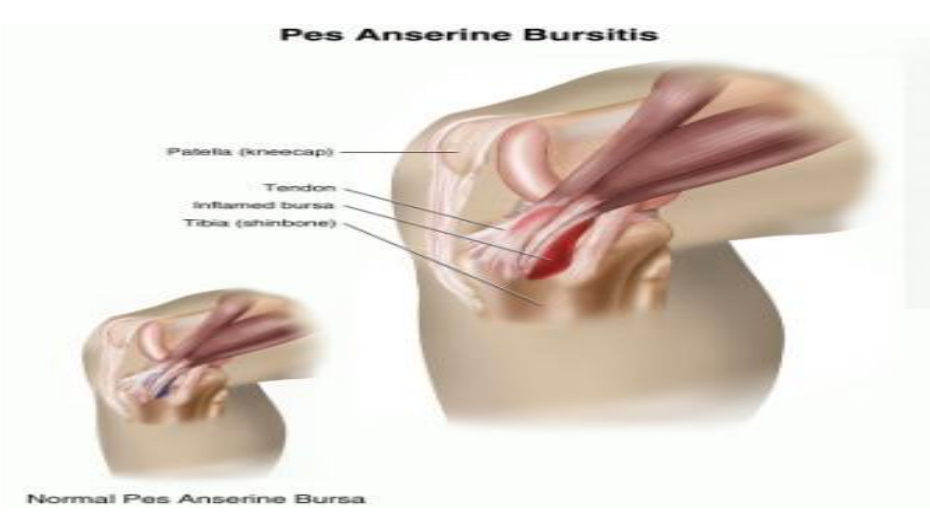

\section{Gambar 3. Pes Bursitis Anserine}

http://www.clinic-hq.co.uk/article_24_Pes+Anserine+Bursitis

E. Penyembuhan Cedera Sendi lutut

Anderson (2009 : 201) meninjau penyembuhan cedera dari jenis dan beratnya cedera. Setiap terapi, baik terapi latihan maupun penggunaan modalitas yang dicatat dalam rencana (plan), bagian dari catatan SOAP (Subjective, Objective, Assessment, Plan) bersama dengan obat yang diresepkan oleh dokter. Mengembalikan kemampuan individu untuk berpartisipasi dalam program latihan terapi dibagi menjadi empat tahap, sebagai berikut :

Fase pertama: mengontrol inflamasi, Fase kedua: mengembalikan gerak, Fase ketiga: mengembangkan kekuatan otot, power, dan daya tahan, Fase ke-empat: mengembalikan ke aktivitas pekerjaan seperti semula.

Beberapa kondisi seperti edema, perdarahan, kejang otot, atrofi, atau infeksi, dapat menghambat proses penyembuhan dan menunda pencapaian tujuan pengobatan jangka pendek. Pengukuran ROM, kekuatan otot, daya tahan, kekuatan, dan kebugaran kardiovaskular secara periodik menentukan apakah kemajuan terjadi. Tujuan utama rehabilitasi adalah mengembalikan pasien yang terluka untuk aktivitas dalam kondisi bebas rasa sakit dan berfungsi penuh. Proses rehabilitasi harus fokus pada pengendalian rasa sakit dan peradangan serta untuk memulihkan ROM berbagai sendi, fleksibilitas, kekuatan otot, daya tahan otot, koordinasi, dan pengendalian. Anderson (2009 : 161) mengatakan bahwa modalitas terapi dan obat-obatan digunakan untuk menciptakan 
lingkungan yang optimal untuk perbaikan cedera dengan membatasi proses inflamasi dan memutus siklus nyeri-kejang. Pilihan penggunaan modalitas tergantung dari saran dokter, lokasi cedera, jenis dan tingkat keparahan cedera.

Menurut Roberts (2011 : 370) modalitas terapi digunakan untuk mengurangi rasa sakit, menghambat pembengkakan, mengurangi kejang, dan mempercepat penyembuhan. Bila digunakan dengan benar, dapat meminimalkan waktu pemulihan. Jika modalitas tersebut digunakan tidak semestinya, justru akan memperburuk kondisi, sehinggga harus diperhatikan indikasi dan kontra indikasi pada modalitas terapi tersebut.

F. Topurak

Topurak adalah manipulasi totok, pukul, dan gerak untuk reposisi sendi, dan dilakukan melibatkan pasien secara langsung untuk mengembalikan sendi ke posisi anatomis. Proses reposisi sendi terdiri atas pelemasan otot, tendo, dan jaringan ikat sekitar sendi menggunakan manipulasi totok dan pukul, yang kemudian diikuti dengan penggeseran (reposisi) sendi dengan gerak terintruksi dan terbantu. Menurut Wara Kushartanti dan Rachmah Laksmi Ambardini (2016 : 73) model reposisi totok, pukul dan gerak ini dimulai dengan penekanan pada "trigger point" (totok) yang akan mempercepat pelemasan otot. Tapotement (pemukulan) akan menyempurnakan pelemasan sehingga mengurangi nyeri pada saat digerakkan. Pergerakan terinstruksi yang dilakukan oleh pasien sendiri akan dapat mereposisi sendi dengan aman karena sesuai dengan kekakuan dan nyeri yang dirasakan.

1 .

Manipulasi Topurak

a. Trigger Point adalah nodul hipersensitif, karena terjadinya kontraksi serabut otot (Lucas, 2007 : 16). Nyeri myofascial adalah nyeri yang berasal dari trigger point myofascial, yang merupakan nodul lokal hipersensitif dalam jaringan otot dan fasia sekitarnya. Ketika titik trigger point ditekan atau diraba akan terasa sakit (Anderson, 2009 : 318). Menurut Dommerholt, Jan (2006 : 205) trigger point digambarkan sebagai tempat hyperirritable pada otot rangka yang berhubungan dengan nodul hipersensitif saat palpasi dalam sebuah otot yang tegang. Trigger point diklasifikasikan sebagai "aktif" (menimbulkan keluhan nyeri klinis) atau "laten" (non-gejala menimbulkan sakit pada palpasi).

b. Nyeri trigger point biasanya konstan, regional, dan biasanya menusuk. Rasa nyeri ini diperburuk oleh gerakan pada postur tertentu, berbeda dengan nyeri neuropatik tertentu, yang umumnya seperti nyeri terbakar atau sensasi listrik (Lucas, 2007 : 18). Terjadinya myofascial trigger point akibat dari berbagai faktor, seperti 
trauma berat, overuse, beban yang terlalu berat, atau stres psikologis (Jeffrey P. Schmidt, 2014 : 9). Trigger point digambarkan sebagai titik yang discrete, focal, hyperirritable, berlokasi di taut band otot skelet. Penekanan pada titik - titik trigger point dimulai dari ujung-ujung origo sampai ke insersio.
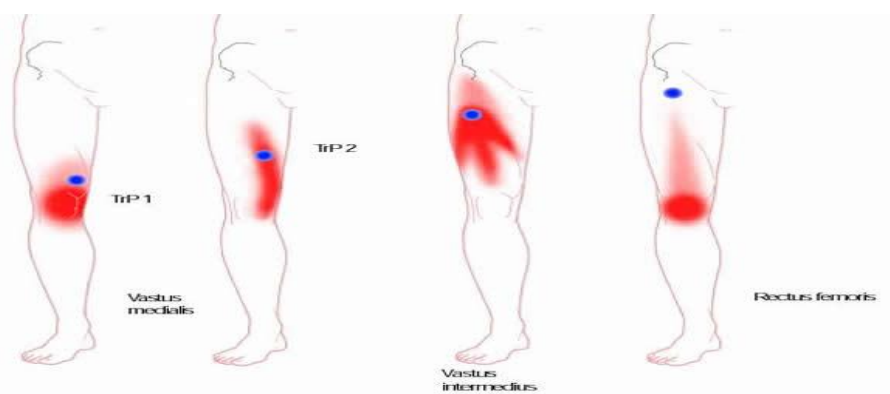

Gambar 4. Quadriceps

http://www.positivehealth.com/img/phfiles/Issue_189/Issue_189_Articles/pain_referral_patte rns_from_pdf.jpg

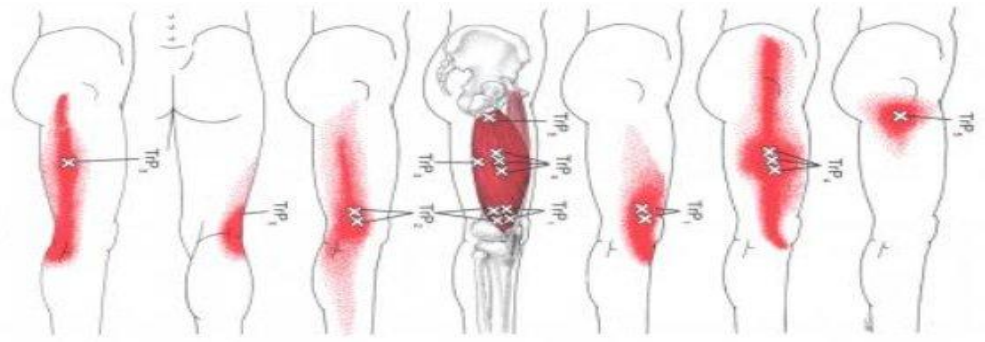

Gambar 5. Vastus Lateralis

http://www.elitepttc.com/wp-content/uploads/Vastus_Lateralis_TP_39_s.jpg

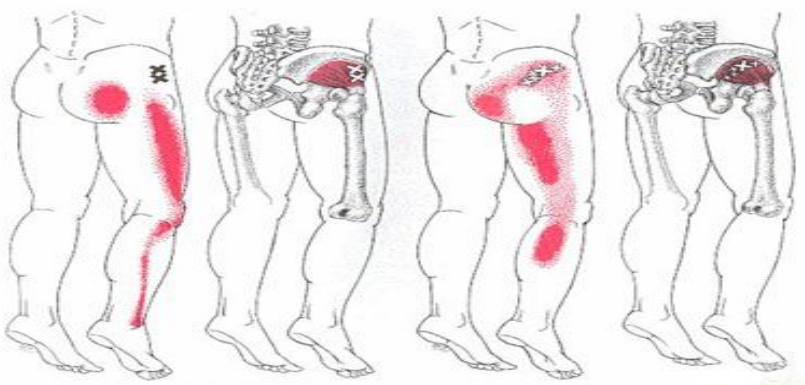

Gambar 6. Gluteus

http://tianlong-acupuncture.com/images/gluteus.jpg

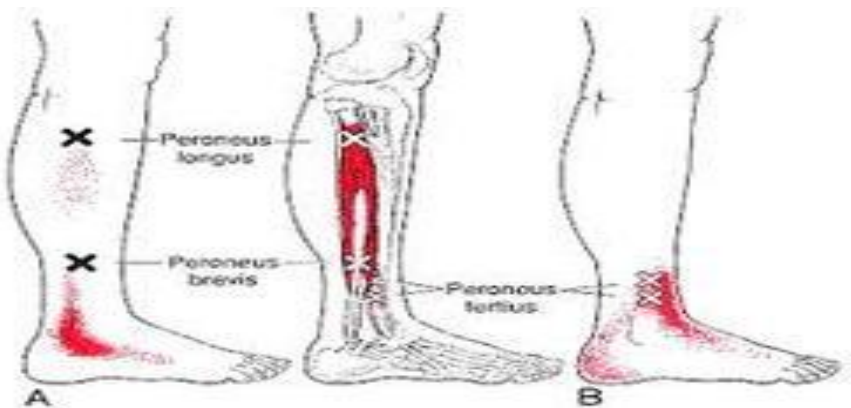

Gambar 7. Gastronemus

Efektifitas Manipulasi “Topurak"untuk penyembuhan Cedera Sendi Lutut Pasien 
http://www.renewacupuncturecare.com/uploads/1/7/8/5/17855851/2117806.jpg?253

c. Tapotement (memukul) adalah teknik pukulan ringan atau perkusi berirama yang diberikan pada bagian yang berdaging. Teknik ini bertujuan untuk menggetarkan jaringan, memicu refleks kulit, menyebabkan vasodilatasi dan meningkatkan respon sensitivitas kontraksi otot. Manipulasi tapotement akan mengurangi pembengkakan dan dengan demikian mempercepat penyembuhan. Ada beberapa teknik tapotement, tetapi yang paling sering dan mudah digunakan adalah "clapping" dengan telapak tangan berbentuk cekungan yang dilakukan pada daerah otot yang besar, "hacking" dengan sumbu ulnar tangan, “beating” dengan jari-jari longgar (Piia Haakana, 2008)

d. Gerak (Gerak Secara Anatomis). Perlakuan gerak pada topurak ini melibatkan gerak secara anatomi yang mengikuti arah gerakan yang dapat dilakukan oleh sendi lutut yaitu gerakan fleksi, ekstensi dan sedikit rotasi.

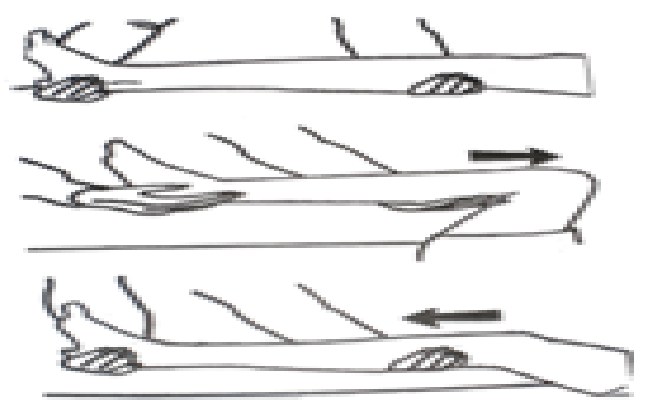

Gambar 8. Fleksi- Ekstensi Lutut

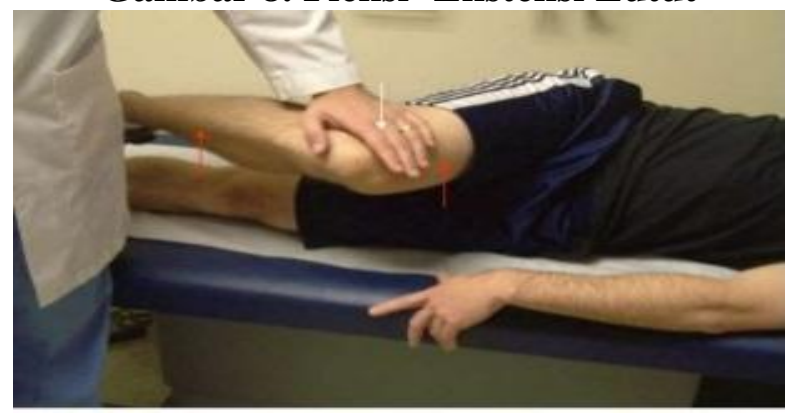

Gambar 9. Rotasi Sendi Lutut

\section{METODE PENELITIAN}

Desain penelitian yang digunakan dalam penelitian ini adalah pre-experimental design dengan rancangan One Group Pretest-Posttest Design, yaitu desain penelitian yang terdapat pretest sebelum diberi perlakuan dan posttest setelah diberi perlakuan dan tanpa kontrol. 
Tabel 1. Treatment Manipulasi Topurak Lutut

\begin{tabular}{|c|c|c|c|c|}
\hline \multirow[t]{2}{*}{ No } & \multirow[t]{2}{*}{ Komponen } & \multicolumn{2}{|l|}{ Manipulasi } & \multirow[t]{2}{*}{ Keterangan } \\
\hline & & Gambar & Narasi & \\
\hline & Totok & $\begin{array}{l}\text { Posisi } \\
\text { terlentang } \\
\text { f }_{x}\end{array}$ & $\begin{array}{l}\text { Melakukan totok } \\
\text { pada titik-titik } \\
\text { trigger point. }\end{array}$ & $\begin{array}{l}\text { Dilakukan selama } \\
1 \text { menit. }\end{array}$ \\
\hline & & $\begin{array}{l}\text { Posisi } \\
\text { telungk } \\
\times \quad 1\end{array}$ & $\begin{array}{l}\text { Melakukan totok } \\
\text { pada titik-titik } \\
\text { trigger point. }\end{array}$ & $\begin{array}{l}\text { Dilakukan selama } \\
\text { 1menit. }\end{array}$ \\
\hline & Pukul & & $\begin{array}{l}\text { Melakukan beating } \\
\text { yang dilakukan } \\
\text { diseluruh } \\
\text { permukaan otot } \\
\text { terutama pada } \\
\text { trigger point. }\end{array}$ & $\begin{array}{l}\text { Manipulasi ini } \\
\text { dilakukan setelah } \\
\text { dilakukan trigger } \\
\text { point yang } \\
\text { dimulai dari } \\
\text { posisi terlentang. } \\
\text { Dilakukan selama } \\
30 \text { detik. }\end{array}$ \\
\hline & Gerak & $\begin{array}{l}\text { Posisi } \\
\text { telungkup }\end{array}$ & $\begin{array}{l}\text { Menekan telapak } \\
\text { kaki hingga } \\
\text { gastrocnemius } \\
\text { tertarik (strecth). }\end{array}$ & $\begin{array}{l}\text { Dilakukan hingga } \\
\text { batas nyeri. } \\
\text { Dilakukan selama } \\
1 \text { menit. }\end{array}$ \\
\hline & & & $\begin{array}{l}\text { Sendi lutut sedikit } \\
\text { diputar dengan } \\
\text { tangan berlawanan. }\end{array}$ & \\
\hline
\end{tabular}




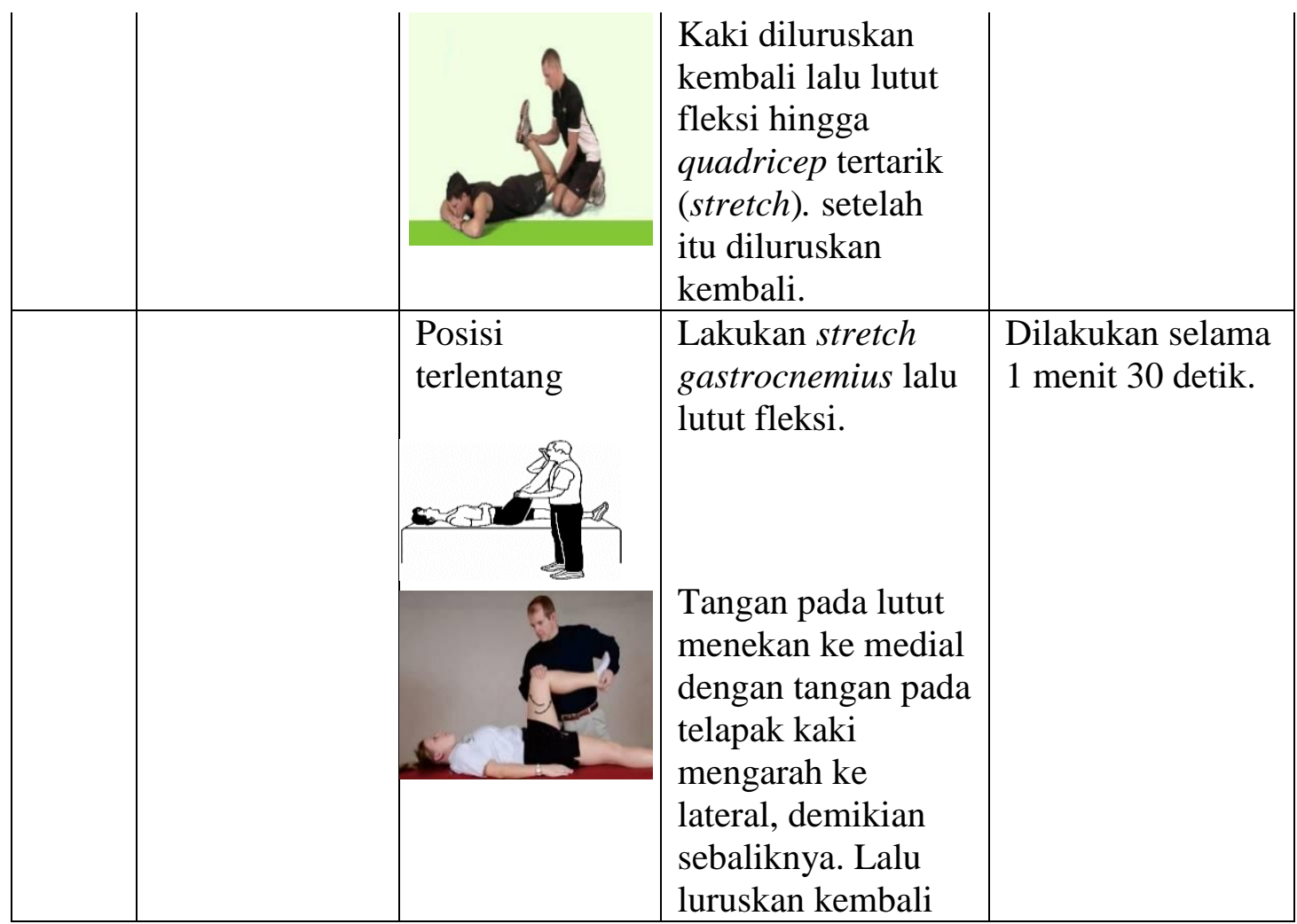

1. Penyembuhan cedera sendi yang dimaksud dalam penelitian ini adalah hilangnya tanda radang, kembalinya range of motion, dan kembalinya fungsi.

2. Cedera lutut yang dimaksud dalam penelitian ini adalah nyeri dan radang pada sendi lutut baik akibat trauma ringan maupun overuse yang mengganggu fungsi gerak sendi lutut.

3. Pasien Lab/ Klinik Olahraga Terapi dan Rehabilitasi FIK UNY merupakan pasien yang meminta layanan terapi di Lab/ Klinik Olahraga Terapi dan Rehabilitasi FIK UNY karena keluhan sendi lutut, dan bersedia menjadi subjek penelitian.

Populasi dalam penelitian ini adalah pasien cedera sendi lutut di Lab/ Klinik Olahraga Terapi dan Rehabilitasi - FIK UNY yang dalam waktu tiga bulan Januari - April 2017 sejumlah 75 orang. Teknik sampling penelitian ini menggunakan Insidental sampling, yaitu yang kebetulan ditemui oleh peneliti, bersedia mengikuti penelitian (dengan mengisi formulir informend consent), berjumlah 20 orang. Penelitian ini menggunakan instrumen berupa catatan medis hasil anamnesis dan pemeriksaan. Catatan anamnesis meliputi riwayat cedera lutut, penyebab cedera, dan beratnya cedera. Poin catatan pada pemeriksaan meliputi tanda radang, lingkar lutut, ROM, skala nyeri dan skala fungsi. Secara rinci instrumen tersaji dalam Tabel 2. 
Tabel 2. Instrumen test baik pada pretest maupun posttest

\begin{tabular}{|c|c|c|c|c|}
\hline \multirow{2}{*}{ No } & Komponen & Sub. Komponen & Teknik & Skala Data \\
\hline & \multirow[t]{3}{*}{ Anamnesa } & Riwayat cedera & Angket & Deskriptif \\
\hline & & Riwayat cedera terdahulu & Angket & Deskriptif \\
\hline & & Riwayat penyakit keluarga & Angket & Deskriptif \\
\hline & \multirow[t]{5}{*}{ Tanda radang } & Merah & Observasi & Ordinal \\
\hline & & Panas & Palpasi & Ordinal \\
\hline & & Bengkak & Lingkar lutut $(\mathrm{cm})$ & Rasio \\
\hline & & Nyeri & Skala & Ordinal/ interval \\
\hline & & Penurunan fungsi & $\mathrm{ROM}\left({ }^{\circ}\right)$ & Rasio \\
\hline & Skala fungsi & Jalan & Skala & Ordinal/ interval \\
\hline & & Duduk dan berdiri kembali & Skala & Ordinal/ interval \\
\hline & & Naik tangga & Skala & Ordinal/ interval \\
\hline
\end{tabular}

\section{HASIL PENELITIAN}

1. Durasi Cedera

Subjek penelitian merasakan cedera lutut rata-rata 6.47 bulan dengan standar deviasi 6.132, dengan kisaran terendah 1 bulan, dan tertinggi 24 bulan. Data durasi cedera terjadi pada gambar 10 .

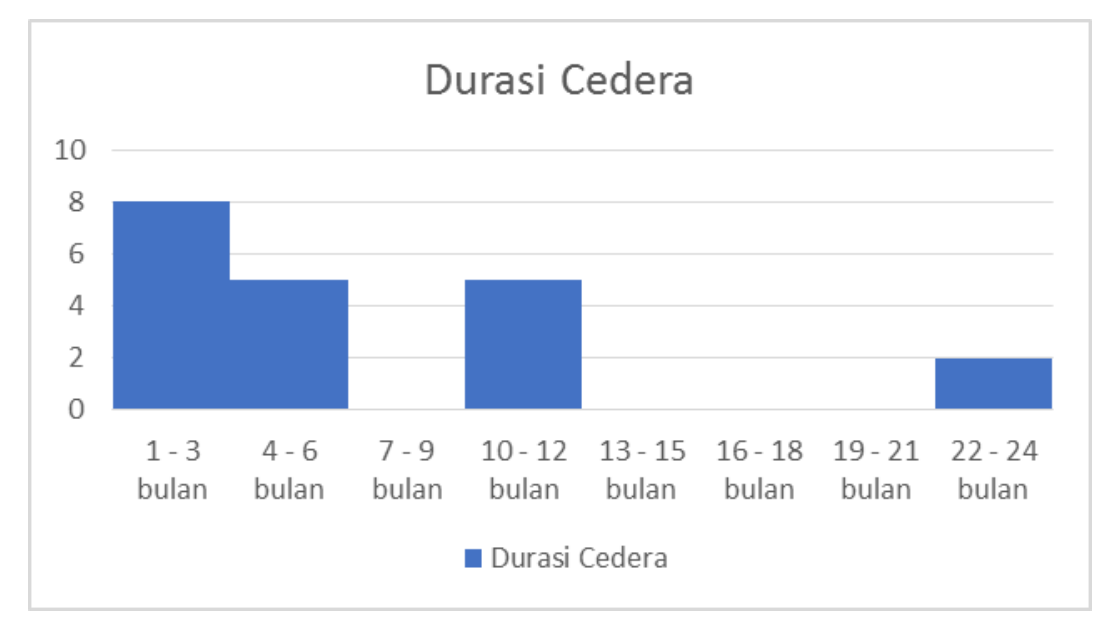

Gambar 10. Histogram Durasi Cedera Subjek

Durasi cedera yang dialami subjek penelitian terbanyak pada kisaran 1-3 bulan yang termasuk pada fase kronis karena cedera relatif tidak dirasakan. Namun ada yang mengalami cedera hingga 22-24 bulan yang termasuk pada fase eksaserbasi akut, cedera kronis yang muncul kembali gejala akut.

2. Penyebab Cedera 
Berdasarkan penyebab cedera, 11 subjek disebabkan akibat trauma sedangkan 9 subjek akibat overuse. Data penyebab cedera tersaji pada grafik berikut ini:

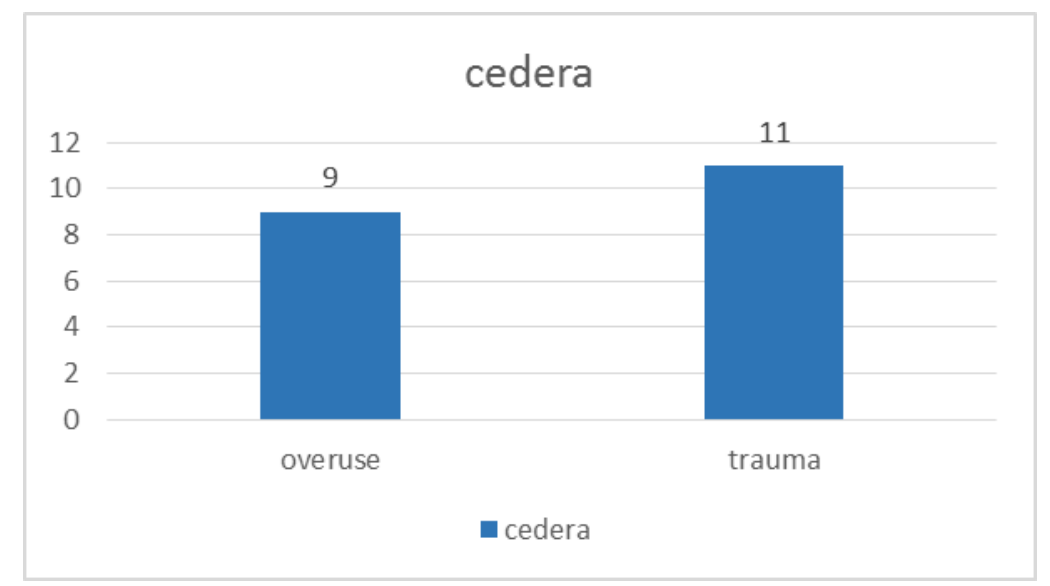

Gambar 11. Histogram Penyebab Cedera Subjek

Cedera overuse sering tidak disadari, dengan gerakan yang berulang-ulang menimbulkan keluhan nyeri. Meskipun tidak dipungkiri bahwa cedera trauma lebih banyak dari pada cedera overuse.

3. Beratnya Cedera

Beratnya cedera subjek penelitian ini dinilai dengan skala 1 sampai 10 (sangat ringan - sangat berat). Data beratnya cedera tersaji dalam Gambar 12 berikut ini:

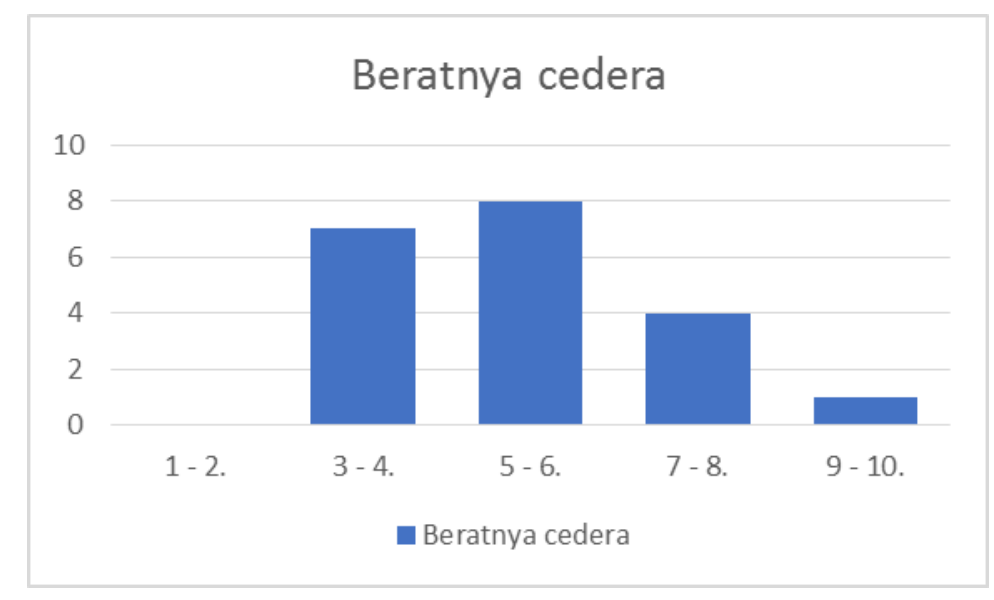

Gambar 12. Histogram Beratnya Cedera Subjek

Beratnya cedera pada skala 1-2 biasanya tidak dihiraukan oleh kebanyakan orang. Pada berat cedera skala 3-8, keluhan akan baru dirasakan dan rata-rata orang cenderung memilih pada pengobatan alternatif. Ketika berat cedera sudah dirasakan skala 9-10 maka orang akan berobat ke rumah sakit. 
4. Cedera Terdahulu

Dari 20 subjek penelitian, 9 orang (45 \%) mengalami cedera kronis dan terjadi berulang-ulang. Hal ini dikarenakan penyembuhan tidak sempurna, setelah merasa tidak nyaman baru melakukan pengobatan.

5. Kemerahan pada Lokasi Cedera

Tabel 3. Intensitas Kemerahan/Rubor

\begin{tabular}{|l|c|c|c|c|}
\hline No & Intensitas Kemerahan & Pre-test & Post-test & Penurunan (\%) \\
\hline 1. & 0 & 16 & 20 & $20 \%$ \\
\hline 2. & 1 & 4 & 0 & \\
\hline 3. & 2 & 0 & 0 & \\
\hline 4. & 3 & 0 & 0 & \\
\hline & Total & 20 & 20 & \\
\hline
\end{tabular}

Subjek penelitian ini rata-rata mengalami cedera kronis sehingga kemerahan pada lutut tidak terlihat meskipun ada 4 subjek terjadi kemerahan ringan. Setelah dilakukan manipulasi Topurak terjadi penurunan kemerahan sebanyak $20 \%$.

6. Suhu pada Lokasi Cedera

\section{Tabel 4. Intensitas Suhu}

\begin{tabular}{|l|c|c|c|c|}
\hline No & Intensitas Suhu & Pre-test & Post-test & Penurunan (\%) \\
\hline 1. & 0 & 7 & 18 & $55 \%$ \\
\hline 2. & 1 & 11 & 2 & $45 \%$ \\
\hline 3. & 2 & 2 & 0 & \\
\hline 4. & 3 & 0 & 0 & \\
\hline & Total & 20 & 20 & \\
\hline
\end{tabular}

Lokasi cedera cedera pada subjek rata-rata bersuhu normal dan sedikit rasa hangat, karena subjek penelitian sudah memasuki fase kronis. Setelah dilakukan manipulasi Topurak suhu pada lutut rata-rata menjadi normal.

7. Lingkar Lutut

Lingkar lutut diukur untuk mengetahui intensitas pembengkakan pada LLA (lingkar lutut atas), LLT (lingkar lutut tengah), dan LLB (lingkar lutut bawah), baik pada pre test maupun post test.

Tabel 5. Lingkar Lutut Kanan

\begin{tabular}{|c|c|c|c|c|}
\hline LLA & Pre test & Post test & Penurunan & Efektivitas (\%) \\
\hline $\bar{X}$ & 42,22 & 41,97 & 0,25 & $0,59 \%$ \\
\hline SD & 5,44 & 5,46 & & \\
\hline & & & & \\
\hline
\end{tabular}




\begin{tabular}{|c|c|c|c|c|}
\hline LLT & Pre test & Post test & Penurunan & Efektivitas (\%) \\
\hline$\overline{\mathrm{X}}$ & 39,07 & 39,25 & $-0,18$ & $0,46 \%$ \\
\hline $\mathrm{SD}$ & 4,78 & 4,35 & & \\
\hline
\end{tabular}

\begin{tabular}{|c|c|c|c|c|}
\hline LLB & Pre test & Post test & Penurunan & Efektivitas (\%) \\
\hline$\overline{\mathrm{X}}$ & 35,52 & 35,45 & 0,07 & $0,19 \%$ \\
\hline $\mathrm{SD}$ & 4,37 & 3,95 & & \\
\hline
\end{tabular}

Tabel 6. Lingkar Lutut Kiri

\begin{tabular}{|c|c|c|c|c|}
\hline LLA & Pre test & Post test & Penurunan & Efektivitas (\%) \\
\hline$\overline{\mathrm{X}}$ & 42,10 & 41,62 & 0,48 & $1,14 \%$ \\
\hline $\mathrm{SD}$ & 5,48 & 5,30 & & \\
\hline
\end{tabular}

\begin{tabular}{|c|c|c|c|c|}
\hline LLT & Pre test & Post test & Penurunan & Efektivitas (\%) \\
\hline $\bar{X}$ & 39,45 & 39,22 & 0,23 & $0,58 \%$ \\
\hline SD & 4,73 & 4,22 & & \\
\hline
\end{tabular}

\begin{tabular}{|c|c|c|c|c|}
\hline LLB & Pre test & Post test & Penurunan & Efektivitas (\%) \\
\hline$\overline{\mathrm{X}}$ & 35,47 & 35,45 & 0,02 & $0,05 \%$ \\
\hline $\mathrm{SD}$ & 3,95 & 3,95 & & \\
\hline
\end{tabular}

Dilihat dari Tabel 5 dan 6 tampak bahwa subjek penelitian hanya sedikit mengalami penurunan bengkak dilihat dari lingkar lututnya. Hal ini disebabkan subjek penelitian mengalami fase kronis sehingga bengkak yang disebabkan karena abnormal pertumbuhan sel baru soft tissue tumor

8. Range of Motion (ROM)

ROM diukur untuk mengetahui sudut fleksi dan ekstensi lutut, baik pada pre test maupun post test.

\section{Tabel 7. Range of Motion Kanan}

\begin{tabular}{|c|c|c|c|c|}
\hline Fleksi & Pre test & Post test & Peningkatan & Efektivitas (\%) \\
\hline $\bar{X}$ & 132,00 & 138,25 & 6,25 & $4,73 \%$ \\
\hline SD & 7,847 & 6,340 & & \\
\hline
\end{tabular}

\begin{tabular}{|c|c|c|c|c|}
\hline Ekstensi & Pre test & Post test & Peningkatan & Efektivitas (\%) \\
\hline $\bar{X}$ & 8,90 & 10,35 & 1,45 & $16,29 \%$ \\
\hline SD & 2,808 & 1,182 & & \\
\hline
\end{tabular}


Tabel 8. Range of Motion Kiri

\begin{tabular}{|c|c|c|c|c|}
\hline Fleksi & Pre test & Post test & Peningkatan & Efektivitas (\%) \\
\hline $\mathrm{X}$ & 131,00 & 139,75 & 8,75 & $6,67 \%$ \\
\hline $\mathrm{SD}$ & 10,834 & 7,159 & & \\
\hline
\end{tabular}

\begin{tabular}{|c|c|c|c|c|}
\hline Ekstensi & Pre test & Post test & Peningkatan & Efektivitas (\%) \\
\hline $\mathrm{X}$ & 9,40 & 10,35 & 0,95 & $10,1 \%$ \\
\hline $\mathrm{SD}$ & 2,780 & 1,569 & & \\
\hline
\end{tabular}

Dari Tabel 7 dan 8 tampak ROM mengalami peningkatan setelah dilakukan manipulasi Topurak, karena setelah dimanipulasi dan direposisi otot dan ROM kembali ke posisi normal sehingga otot menjadi lebih rileks.

9. Skala Nyeri

Nyeri dimulai dengan skala 0 - 10, semakin nyeri semakin tinggi skala. Dari 20 subjek penelitian, data skala nyeri tersaji dalam Tabel 9.

Tabel 9. Skala Nyeri Subjek Penelitian

\begin{tabular}{|c|c|c|c|c|}
\hline & Pre test & Post test & Penurunan & Efektivitas (\%) \\
\hline $\bar{X}$ & 7,35 & 2,85 & 4,5 & $61,63 \%$ \\
\hline $\mathrm{SD}$ & 1,495 & 1,309 & & \\
\hline
\end{tabular}

Pada tabel di atas terlihat penurunan nyeri dengan skala 4,5 karena manipulasi topurak dapat merilekskan otot dan ROM kembali ke posisi normal sehingga nyeri akan menurun.

10. Kemampuan Jalan

Kemampuan berjalan diukur dengan skala fungsi berjalan, semakin baik fungsi berjalannya semakin tinggi skala. Dari 20 subjek penelitian dilakukan pre-test dan posttest, ini tersaji dalam Tabel 10.

Tabel 10. Skala Fungsi Jalan

\begin{tabular}{|c|c|c|c|c|}
\hline & Pre test & Post test & Peningkatan & Efektivitas (\%) \\
\hline$\overline{\mathrm{X}}$ & 8.50 & 9.60 & 1,1 & $12.94 \%$ \\
\hline $\mathrm{SD}$ & 1.821 & 0.681 & & \\
\hline
\end{tabular}

Dari histogram di atas tersaji bahwa peningkatan skala jalan meningkat 1,1, karena manipulasi Topurak ROM menjadi normal dan nyeri menurun sehingga dapat meningkatkan kemampuan berjalan. 
11. Kemampuan Berdiri Setelah Duduk

Kemampuan berdiri setelah duduk diukur dengan skala, semakin baik fungsi tersebut semakin tinggi skala. Dari 20 subjek penelitian dilakukan pre-test dan post-test, ini tersaji dalam Tabel 11.

Tabel 11. Skala Fungsi Berdiri Setelah Duduk

\begin{tabular}{|c|c|c|c|c|}
\hline & Pre test & Post test & Peningkatan & Efektivitas (\%) \\
\hline $\mathrm{X}$ & 7,05 & 8,90 & 1,85 & $26,24 \%$ \\
\hline $\mathrm{SD}$ & 2,481 &, .252 & & \\
\hline
\end{tabular}

Kemampuan duduk lalu berdiri terjadi peningkatan 1,85 yang tersaji pada histogram di atas. Manipulasi Topurak dapat meningkatkan kemampuan duduk lalu berdiri karena kemampuan berjalan meningkat dan rasa nyeri berkurang.

12. Kemampuan Naik Tangga

Kemampuan naik tangga diukur dengan skala, semakin baik fungsi tersebut semakin tinggi skala. Dari 20 subjek penelitian dilakukan pre-test dan post-test, ini tersaji dalam Tabel 12.

\section{Tabel 12. Skala Funsi Naik Tangga}

\begin{tabular}{|c|c|c|c|c|}
\hline & Pre test & Post test & Peningkatan & Efektivitas (\%) \\
\hline$\overline{\mathrm{X}}$ & 6,70 & 8,30 & 1,6 & $23,88 \%$ \\
\hline $\mathrm{SD}$ & 2,755 &, .922 & & \\
\hline
\end{tabular}

Dilihat dari histogram di atas terjadi peningkatan skala naik tangga 1,6, karena penurunan rasa nyeri, peningkatan berjalan dan duduk lalu berdiri setelah dilakukan manipulasi topurak sehingga terjadi peningkatan dalam skala naik tangga.

\section{PEMBAHASAN}

Pada penelitian ini, durasi cedera terbanyak pada 1 hingga 3 bulan, dengan penyebab cedera $55 \%$ karena trauma, dan beratnya cedera terbanyak terjadi 5-6 dari skala 1-10. Penyembuhan merupakan proses di mana respons alami tubuh terhadap perbaikan cedera atau penggantian jaringan dengan tujuan pemulihan tubuh ke keadaan pra cedera. Shields (2013: 1) mengatakan jaringan skala mikroskopis akan sembuh dengan regenerasi melalui fase inflamasi. Hal ini tergantung pada jenis jaringan yang cedera dan faktor fisiologis. Faktor fisiologis ini dapat mengurangi efisiensi penyembuhan misalnya usia, vaskularisasi, adanya diabetes, infeksi dan malnutrisi. 
Cedera pada subjek penelitian kebanyakan terjadi karena trauma. Hal ini disebabkan karena keseimbangan tubuh tidak bisa memberikan kestabilan postur yang baik sehingga berpotensi terjatuh dan terjadi cedera. Menurut D F, Murphy (2003: 21) studi telah menunjukkan kekuatan otot atau ketidak seimbangan menjadi faktor risiko untuk cedera pergelangan kaki, cedera lutut, dan cedera overuse. Subjek penelitian lebih banyak tidak mengalami kemerahan pada lutut karena, kondisi cedera sudah memasuki fase kronis. Dilihat dari pre test 16 orang negatif kemerahan dengan 4 orang terjadi kemerahan positif 1 . Setelah dilakukan Manipulasi Topurak terjadi peningkatan dengan subjek negatif kemerahan 20 orang. Intensitas suhu pada subjek penelitian kebanyakan terjain suhu dengan positif 1 , setelah dilakukan manipulasi topuran terjadi penurunan suhu.

Hasil analisis data penelitian membuktikan bahwa Manipulasi Topurak untuk penyembuhan sendi lutut pasien Lab/Klinik Olahraga Terapi dan Rehabilitasi FIK UNY mempunyai efektivitas yang signifikan untuk penyembuhan sendi lutut. Hasil sign test diketahui bahwa terdapat peningkatan pada fungsi, ROM, dan penurunan rasa nyeri. Cedera lutut banyak dialami dimasyarakat, baik cedera secara overuse maupun trauma. Banyak faktor intrinsik maupun ekstrinsik yang menyebabkan cedera lutut, diantaranya jenis kelamin, berat badan, komposisi tubuh, fleksibilitas, kekuatan ekstensi kaki, melompat tinggi, $Q$-angle, stabilitas sendi, dan riwayat cedera sebelumnya (D F Murphy, 2003: 13). Cedera lutut dapat menyebabkan terjadinya peradangan yang terdiri dari rubor (merah), kalor (panas), tumor (bengkak), dolor (nyeri), dan penurunan fungsi (functiolaesa), sehingga membutuhkan penanganan yang tepat agar cedera tidak berkepanjangan dan mempercepat proses penyembuhan.

\section{KESIMPULAN}

Manipulasi Topurak efektif dalam penyembuhan cedera lutut kronis pada pasien. Hasil ini dapat dijelaskan karena dalam Manipulasi Topurak terdapat tindakan-tindakan yang berfungsi untuk menangani cedera lutut. Penatalaksanaan Manipulasi Topurak pada sendi lutut dilakukan dari posisi terlentang maupun telungkup sehingga efektif dalam menyembuhkan sendi lutut. Penanganan Manipulasi Topurak dimulai dari posisi terlentang dan telungkup dengan memberikan totok pada trigger point untuk melemaskan otot, lalu melakukan pukulan tapotement pada otot-otot yang diberikan totokan sebagai penyempurna pelemasan otot, dan diberikan gerakan-gerakan terinstruksi yang dilakukan pasien pada sendi lutut seperti fleksi, ekstensi dan sedikit rotasi dari posisi telungkup dan dilanjut dengan posisi terlentang. 
Manipulasi Topurak mempunyai efektivitas yang signifikan pada penyembuhan sendi lutut terhadap pasien Klinik/ Lab Olahraga Terapi dan Rehabilitasi FIK UNY. Hal ini dapat diartikan bahwa Manipulasi Topurak dapat digunakan pada cedera subluksasi sendi lutut. Penanganan cedera secara cepat dengan menggunakan metode yang tepat dapat mendukung proses penyembuhan cedera secara tuntas dan sempurna. Secara keseluruhan dapat disimpulkan bahwa manipulasi Topurak sebanyak tiga kali dengan durasi masing masing 5 menit, dapat menyembuhkan cedera sendi lutut dengan indikasi berkurangnya radang (merah, panas, bengkak, dan nyeri), serta meningkatnya fungsi sendi lutut untuk kegiatan sehari-hari (jalan, berdiri dari duduk, dan naik tangga) dengan signifikan.

\section{DAFTAR PUSTAKA}

Arif Setiawan. (2011). "Faktor Timbulnya Cedera Olahraga". Jurnal Media Ilmu Keolahragaan Indonesia. Vol. 1, No. 1. Hlm: 94-98

Bambang Priyonoadi. (2011). Sport Massage. Yogyakarta: FIK UNY.

Eka Pratiwi Maharani. (2007). "Faktor-Faktor Risiko Osteoartritis Lutut (Studi Kasus di Rumah Sakit Dokter Kariadi Semarang)". Tesis. UNDIP: Semarang.

Fitriani Lumongga. (2004). Sendi Lutut. FK Universitas Sumatera Utara : Sumatra Utara.

John P. DiFiori, dkk. (2014). "Overuse Injuries and Burnout in Youth Sports: A Position Statement from the American Medical Society for Sports Medicine". Journal Clin J Sport Med. Vol. 24, No. 1. Hlm. 3-20.

Heather K. Vincent, dkk. (2012) "Weight Loss and Obesity in the Treatment and Prevention of Osteoarthritis". Journal Author Manuscript. Vol. 4 No. 5. Hlm 59 - 67.

Helen C. Smith, dkk. (2012). "Risk Factors for Anterior Cruciate Ligament Injury: A Review of the Literature-Part 2: Hormonal, Genetic, Cognitive Function, Previous Injury, and Extrinsic Risk Factors". Journal Sports Health. Vol 4. No. 2. Hlm 155-161.

Kalyani Premkumar. (2004). "The Massage Connection: Anatomy and Physiology". Canada : University of Calgary.

Kurre W. Ostrom. (2000). "Massage and The Original Swedish Movements". Swedia : Royal University Of Upsala.

Larry W. McDaniel. (2010). "Reducing The Risk Of ACL Injury In Female Athletes". Journal Contemporary Issues In Education Research. Vol. 3, No. 3. Hlm 15-20.

Michel P.J. van den Bekerom,dkk. (2012). "What Is the Evidence for Rest, Ice, Compression, and Elevation Therapy in the Treatment of Ankle Sprains in Adults?". Journal of Athletic Training. Vol. 47, No. 4. Hlm : 435-443). 
Muhammad Ikhwan Zein. (2016). Pertolongan Pertama Cedera. Yogyakarta : FIK.

Murphy, D F. (2003). "Risk Factors for Lower Extremity Injury: a Review of the Literature". Journal Sports Med. Vol. 37. No. 1. Hlm 13-29.

Pornratshanee Weerapong, dkk. (2005). "The Mechanisms of Massage and Effects on Performance, Muscle Recovery and Injury Prevention". Journal Sports Med Vol. 35, No. 3. Hlm 235-256.

Rachmah Laksmi Ambardini \& B.M. Wara Kushartanti. (2016). "Efektivitas Masase Topurak Untuk Reposisi Subluksasi Bahu”. Proceedings FIK UNY. Hlm 73-82.

Robert. C, France (2011). Introduction to Sports Medicine and Athletic Training Second edition. USA : Clifton Park, NY. 